Contacts

Publisher: Ben Crowe

Editor: Paul Smaglik

Marketing Manager: David Bowen

European Head Office,

London

The Macmillan Building

4 Crinan Street

London N1 9XW, UK

$\mathrm{Tel}+44$ (0) 2078434961

Fax +44 (0) 2078434996

e-mail: naturejobs@nature.com

Naturejobs Sales Director

Nevin Bayoumi (4978)

UK/ RoW/ Ireland:

Matt Powell (4953)

Andy Douglas (4975)

Frank Phelan (4944)

Netherlands/ Italy/ Spain/

Portugal/ Belgium:

Evelina Rubio Hakansson (4973)

Scandinavia: Sille Opstrup (4994)

France/ Switzerland:

Amelie Pequignot (4974)

Natureevents:

Paul Constant (4954)

Production Manager: Billie Franklin

To send materials use London

address above.

Tel +44 (0) 2078434814

Fax +44 (0) 2078434996

e-mail:naturejobs@nature.com

Naturejobs web development:

Tom Hancock

Naturejobs online production

Ben Lund

European Satellite Office

Germany/ Austria:

Patrick Phelan, Odo Wulffen

Tel + $498954905711 /-2$

Fax +498954905720

e-mail: p.phelan@nature.com

o.wulffen@nature.com

US Head Office, New York

345 Park Avenue South,

10th Floor, New York, NY 10010-1707

Tel +1 8009897718

Fax +18009897103

e-mail:naturejobs@natureny.com

US Sales Manager: Peter Bless

US Advertising Coordinator

Linda Adam

Japan Head Office, Tokyo

MG Ichigaya Building (5F),

19-1 Haraikatamachi,

Shinjuku-ku,

Tokyo 162-0841

Tel +81332678751

Fax +81332678746

Asia-Pacific Sales Director:

Rinoko Asami

e-mail: rasami@naturejpn.com

\title{
naturejobs
}

\section{Forcing the market}

A

report by the National Science Foundation, issued on 24 November, paints a picture of a slowly declining US science workforce. The document, called The Science and Engineering Workforce: Realizing America's Potential, points to a steady slide in student enrolment for maths and physics over the past few years, projects mass retirements in key science and engineering areas over the next two decades, and predicts a decline in the number of foreign scientists who are willing — or allowed — to pick up the slack.

After reading this report, someone with no conception of the realities of the $\mathrm{PhD}$ job market might react with dismay, and agree with some of the conclusions that the report draws. The US education system is somehow failing. There won't be enough skilled scientists to meet the demand for qualified positions. The US 'dominance' in science and engineering is threatened - and that this a grave thing, indeed.

A cynic or a sceptic, however, is more likely to say that actually this a positive thing, because it might drive salaries up and improve conditions for PhDs. It might hurt people who rely on cheap and plentiful postdoc labour in the short term, but why should they be continually rewarded for exploitative practices anyway? And as for the perceived shortage of people willing to come to the United States - they're not to blame if a restrictive visa policy makes them consider alternative locations.

The reality is that market forces are contributing to the decline of young people taking degrees in science and industry - not just in the United States but in Europe as well. Not to worry market forces will sort out the situation, with the best talent going to places that are willing to let them work there with a minimum amount of immigration hassle, pay them fairly and provide the infrastructure to attract and keep them there.

\section{Paul Smaglik}

Naturejobs editor
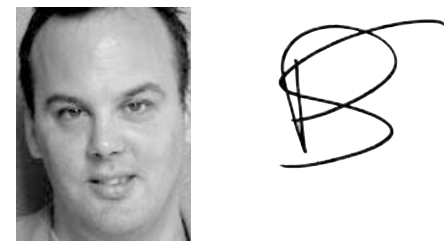

\section{Contents}

\section{CAREERS AND RECRUITMENT}

The developing role of HIV/AIDS research

\section{WWW.NATUREJOBS.COM}

Career centre

Information on the scientific job market

FOCUS

SPOTLIGHT

RECRUITMENT

ANNOUNCEMENTS

EVENTS 